\title{
Revisitando a tutela do consumidor nos precedentes históricos e no Direito pátrio
}

\author{
Carlos Silveira Noronha*
}

\section{DOS PRECEDENTES HISTÓRICOS}

No concerto histórico-universal os bens de consumo e serviços sempre estiveram presentes na vida do ser humano, como exigência necessária, material, fisiológica, psicológica e hedonística da humanidade, no endereço à satisfação de suas necessidades. Pode-se conceber a presença da relação de consumo e dos seus elementos compositivos (fornecedor-consumidor - produto de consumo) nos mais recônditos tempos da ancestralidade, ainda que nas origens imemoriais da pessoa humana se pudesse confundir a individualidade do produtor com a do consumidor, como se pode supor dos relatos bíblicos do Gênesis, quando o
Criador impôs a Adão a sentença divina "ganharás o pão com o suor do teu rosto".

Essa realidade não escapou à percepção dos espíritos mais agudos da Antigüidade Clássica, pois se sabe que, em época áurea da cultura romana (século I a.C.), propusera Cícero fosse assegurada garantia ao comprador de mercadoria eivada de vício oculto, adquirida em razão de anúncio ou apregoação de qualidades não verdadeiras, à instância do vendedor, ${ }^{1}$ podendo aí configurar-se a fonte mais remota dos vícios redibitórios.

No direito moderno, a tutela do consumidor acelerou-se a partir do epílogo do anterior e início do presente século, sob o influxo da chamada Revolução Industrial. Os mecanismos

\footnotetext{
* Professor titular de Direito Civil da Faculdade de Direito da UFRGS; especialista, mestre e doutor em Direito pela USP.

1 Cícero, De officiis, 3.17.76, in Oeuvres complètes de Cicéron, Paris, Ed. Garnier, s.d.
} 
criados para a sua proteção espraiamse por três grandes sistemas: o da common law o da civil law e o socialista. Este último, no entanto, não oferece maior interesse para as comunidades do mundo ocidental, por estar sujeito a modelos econômicos e políticos bem diversos.

As primeiras experiências modernas situam-se efetivamente na família dos sistemas da common law, através de construções da jurisprudência, com base na equity, inicialmente no sistema inglês e posteriormente no sistema norteamericano, onde podem ser destacados os casos Longmeid v. Holliday, em 1851, e Donoghue v. Stevenson, em 1932, cujas sentenças foram proferidas pela House of Lords, na Inglaterra, bem como os casos Thomas $v$. Winchester, em 1852, e Mac Pherson v. Buick Motor Co., em 1916, nos Estados Unidos, em tema de responsabilidade do fabricante pelo fato do produto. Nessas hipóteses, os tribunais prolatores das sentenças, amparandose num dever geral de diligência (duty of care) que o fabricante devia ter perante terceiros, no processo de fabricação e distribuição dos seus produtos, superaram o princípio do privity of contract, que havia sido consagrado no caso Winterbottom $v$. Wright, julgado em 1842. ${ }^{2} \mathrm{No}$ âmbito da reparação no sistema norte-americano, o mecanismo mais utilizado é a class action, originária do direito inglês e introduzida no direito estadunidense com a Federal Equity Rule 38, de 1912 , onde atingiu maior relevância a partir da Regra 23 das Federal Rules of Civil Procedure, de 1938. As mais importantes eram a true class action, a hybrid class action e a spurious class action, que sofrem adaptações para utilização nos tribunais estaduais. ${ }^{3}$

No direito europeu-continental, a tutela do consumidor nasceu com maior vigor na França, onde, ao abordar a doutrina dos contratos, Saleilles invocava, em 1901, a necessidade de maior proteção do aderente, diante do desprestígio do princípio da autonomia da vontade, em razão da disparidade de forças entre as partes nos contratos de adesão. ${ }^{4}$ Foi ali que também nasceu, no contexto do sistema de direitos caracterizador da família civil law, o primeiro diploma positivo para proteger o consumidor - a lei de $1^{\circ}$ de agosto de 1905 -, que visava reprimir todos os embustes sobre a qualidade, quantidade, origem e distorções no preço dos

2 Luiz Gastão Paes de Barros Leães, A responsabilidade do fabricante pelo fato do produto, São Paulo, Saraiva, 1987, p. 29-47.

3 José Rogério Cruz e Tucci, "Class action" |e mandado de segurança coletivo, São Paulo, Saraiva, 1990, p. 11-2.

4 Carlos Alberto Bittar, Os contratos de adesão e a defesa do consumidor, RTJESO, 122:26-38. 
produtos, praticados por fabricantes ou comerciantes inescrupulosos. ${ }^{5}$

A França, como não tivesse, então, codificação específica sobre o assunto, desde o início do século vinha editando um elenco de importantes diplomas legislativos com o objetivo de enfrentar as relações de consumo. Tais são as Ordonnances n. 45-1483 e 45-1484, de 30 de junho de 1945, que estabelecem regras sobre a fixação do preço das mercadorias; a Loi Royer, n. 73-1193, de 27 de dezembro de 1973, que instituiu as ações coletivas; as Leis Scrivener n. 78-22 e 78-23, de 10 de janeiro de 1978, que proscreveram as cláusulas abusivas nos contratos, e muitas outras. ${ }^{6} \mathrm{Na}$ atualidade tem a França seu Code de la consommation, editado com a Lei n. 93-949, de 26.07.1993.

Outros países, como a Suécia com o seu Consumer Ombudsman, de 1969, a República Federal Alemã, com a $A G B$-Gesetz, de 9 de dezembro de 1976 , a primeira lei a proscrever as cláusulas abusivas; Portugal, com a sua Lei de Defesa do Consumidor (Lei $n$. 29/81, de 22-8-1981); a Espanha, com a sua Ley General para Defensa de los Consumidores y Usuarios, n. 26/ 84, de 19 de julho de 1984; e, finalmente, as Diretivas da Comunidade Econômica Européia para a disciplina das relações de consumo nos países que a integram, completam o elenco normativo acerca da proteção do consumidor no Velho Continente.

$\mathrm{Na}$ América Latina, o México foi o primeiro Estado a editar diploma legal pertinente ao assunto, o qual se acha consubstanciado na Lei Federal de Proteção ao Consumidor, de 5 de fevereiro de $1976 .{ }^{7}$

No Brasil, a proteção do consumidor apresenta-se como tema novo, quase contemporâneo aos nossos dias. Efetivamente, só a partir da Revolução de 1930 começa a despertar a consciência nacional no sentido de abandonar o liberalismo político, econômico e jurídico fundado na igualdade formal dos postulados iluminísticos, que desde muito já haviam olvidado o outro postulado, o da fraternidade, evocado pela Revolução Francesa. E essa tomada de consciência, a par da insatisfatória evolução cultural, social e política,

\footnotetext{
5 Bernard Bouloc, La loi de 1905 en tant qu'instrument de la sécurité des consommateurs, in Sécurité des consommateurs et responsabilité du fait des produits défecteux (Colloque des 6 et 7 novembre 1986, organisé par le Centre de Droit des Obligations de l'Université de Paris I, Pantheon Sorbonne), dir. Jacques Ghestin, Paris, LGDJ/R. Pichon et R. DurantAuzias, 1987, p. 13.
}

6 Philippe Malinvaud, La protection du consommateur en droit français, Revista de Direito Comparado Luso-Brasileiro, Rio de Janeiro, Forense, 5:41-58, 1986.

7 Carlos Alberto Bittar, Direitos do consumidor, Rio de Janeiro, Forense Universitária, 1990, n. 7, p. 11-4. 
tornou-se ainda mais penosa diante da intervenção do Estado no conflito mundial de 1939-1945, que trouxe sérios transtornos à sua economia e desenvolvimento em todos os setores da vida nacional. No contexto econômico, teve o povo que enfrentar e não raro se submeter ao recrudescimento de um capitalismo anterior a 1939 , senão a 1914, dominado por grandes grupos empresariais integrados entre si, formando monopólios ou oligopólios impositores dos preços ao consumidor, de modo que a concorrência resultava apenas aparente, com real subversão desse princípio basilar da chamada economia de mercado. ${ }^{8}$

Tais acontecimentos, aliados aos estágios intermitentes de instabilidade política por que passou o País nesse período pós-guerra, fizeram com que a conscientização do povo quanto à satisfação de suas necessidades em direção a uma melhor qualidade de vida enfrentasse obstáculos muito sérios.

\section{DA TUTELA DA RELAÇÃO DE CONSUMO, EM GERAL}

O vocábulo tutela, traduz a idéia de amparo, proteção, defesa, apoio e guarda, em sentido genérico. Sua origem etimológica está na palavra homógrafa do nominativo latino tutela, tendo sido usada na acepção jurídica por Cícero, em Pro Caecina. E, com tal semântica, trasladou-se para a linguagem jurídica moderna, passando a significar, neste ramo do conhecimento científico, a proteção que a ordem jurídica se propõe a conferir às pessoas, aos bens e às relações que dela venham a necessitar para se resguardar das ameaças de lesão dos seus direitos ou para se recuperar de lesões efetivamente sofridas.

$\mathrm{Na}$ verdade, há na relação de consumo, como em outros setores da ordem jurídica, uma bipolarização da tutela, que se opera em dois planos: $n o$ plano do direito material e no plano da jurisdição.

\subsection{Da tutela do consumidor no plano do direito material}

De notar, inicialmente, que a noção de direito individual vem cedendo espaço à noção de direito social em decorrência da elevação deste último à categoria de direito de segunda geração, pertencente à escala dos direitos fundamentais, notadamente em face do surgimento da concepção de Estado Social (Welfare state), nos tempos modernos. Assim, a partir do segundo quartel do século $X X$, vêm se destacando do direito subjetivo individual clássico os chamados direitos supraindividuais (difusos e coletivos).

Diante de tal perspectiva, para analisar os mecanismos de tutela do

8 Sobre o assunto, v. Luiz Otávio de Oliveira Amaral, História e fundamentos do direito do consumidor, RT, 648:31-45. 
consumidor no plano do direito material, dividimo-la em dois setores: o legislativo e o administrativo.

\subsubsection{Dos mecanismos legislativos}

A tutela dos direitos do consumidor no Brasil, no âmbito legislativo, constitui tema deveras recente, não obstante tenham surgido a partir do segundo quartel do século recém findo algumas leis que, embora visando a proteção a outros segmentos da vida social e econômica, tenham ensejado uma tutela indireta às relações de consumo. No modelo legislativo, sem dúvida, reside a fonte normativa para os demais tipos de tutela aos direitos do consumidor, como de resto o seria para qualquer outra atividade. Aqui se manifesta essencialmente a função do Estado-legislador.

A primeira dentre as leis desse tipo pode-se identificar no Código Civil de 1916, com a disciplina dos vícios redibitórios (arts. 1.101 a 1.106), instituição essa de características nitidamente clássicas que vinha cuidando da qualidade do produto mediante a mesma ótica, instituída desde o sistema romano, onde adquiriu suas características atuais. Apesar disso e se não estivesse inserto em sistema jurídico dominado pelo relativismo contratual estabelecido no artigo 928 do Código Civil de 1916, e pela teoria da culpa estatuída no artigo 159 , o instituto poderia ter oferecido melhor tutela aos interesses do consumidor, como ocorreu na França com a action en garantie de vices cachés, de que trata o artigo 1.648 do Code Civil, o qual, com os suprimentos introduzidos pela jurisprudência, vinha dando efetiva proteção aos ditos interesses, como informa Mazeau, in Leçons, tome trezième, p. 808-812, Ed. Monchresten, 1966. Atualmente o tema está regulado pelo Code de la consommation (Lei n. 93949, de 26.07.1993). Mas, no panorama nacional, a ação redibitória limitava-se a alguns alargamentos do prazo decadencial curtíssimo do então artigo $178, \S 2^{\circ}$, do Código anterior, pela ação dos tribunais. Nada mais além disso.

Entre nós, outras leis de cunho protetivo da população têm sido editadas. Começaram com a Lei da Usura (Dec. n. 22.626/33), limitativa da taxa de juros e das cláusulas penais, mas os juros passaram, para as instituições financeiras, a ser liberados ao talante do Conselho Monetário Nacional, instituição pública de características liberais, criada pela Lei da Reforma Bancária (art. $3^{\circ}$ da lei n. 4.595/64), com apoio na súmula 596 do Supremo Tribunal Federal. Seguem-se o decreto-lei n. 869/38, que define e penaliza os crimes contra a economia popular e abusos do poder econômico; a chamada Lei da Economia Popular (lei n. 1.521/51), ampliando o diploma anterior; a Lei de Repressão ao Poder Econômico (lei n. 4.137/62), que cria o Conselho Administrativo de Defesa Econômica - CADE, para a repressão do abuso e regular a concorrência. 
Toda essa gama de diplomas legislativos dirigiu-se para a disciplina normativa de outros segmentos setoriais da economia e da comunidade. E, não obstante tivesse por escopo a melhoria da qualidade da vida nacional, não ofereceu senão tutela indireta ou reflexa aos direitos do consumidor.

Em termos de legislação protetiva indireta, mister se faz referir, por fim, a teoria do abuso de direito, originária da jurisprudência francesa, que não foi acolhida pelo Código Civil pátrio de 1916, uma vez que na época ainda não se havia firmado uma proteção mais efetiva do consumidor, devido à prevalência ainda muito forte do direito subjetivo individual clássico. O novo Código Civil, certamente inspirado no art. 334 do Código português, cuida do abuso de direito no art. 187 , cuja redação é a seguinte: Também comete ato ilícito o titular de um direito que, ao exercêlo, excede manifestamente os limites impostos pelo seu fim econômico ou social, pela boa-fé ou pelos bons costumes. Entendem alguns civilistas, entre os quais o saudoso Prof. Carlos Alberto Bittar, que há lesões de direitos do consumidor nas quais se caracteriza o abuso de direito, razão por que resultaria aplicável essa disposição do direito pátrio, para salvaguarda do mesmo. ${ }^{9}$

Tal proteção só passou a ser encarada com maior seriedade no Brasil a partir do último quartel do século passado e mais precisamente nos primeiros albores da década de $80, \mathrm{com}$ a legitimação do Ministério Público para a propositura da ação civil pública (LC n.40/81) e a completa disciplina desta pela lei n. 7.347/85, bem como através do decreto n. $91.469 / 85$, editado concomitantemente à mesma lei, criando o Conselho Nacional de Defesa do Consumidor - CNDC, para a formação e condução da política nacional de defesa do consumidor. Mas, a par desta última providência de natureza legislativa, visando estruturar uma consciência nacional de proteção ao consumidor, e ainda que a lei da ação civil pública estendesse sua disciplina a esse mister, como integrante dos chamados interesses difusos, carecia ainda a comunidade nacional de normatização política fundamental e de um estatuto específico para cuidar das relações de consumo.

A primeira carência foi substancialmente suprida pela Carta Política de 1988 (arts. $5^{\circ}$, XXXII, e 170, V; disposições constitucionais transitórias, art. 48), que integrou o Brasil no concerto das nações mais preocupadas com a tutela do consumidor, cujos cuidados com o mister se projetam ainda que timidamente, desde o início do século anterior. Parece não restar dúvida de que o legislador constituinte foi sensível à recomendação da $\mathrm{ONU}$, na Resolução n. 39/248, de 10 de abril

9 Carlos Alberto Bittar, Os contratos de adesão e o sancionamento de cláusulas abusivas, RT, 648:17-20; Responsabilidade civil, Forense Universitária, 1989, n. 47, p. 54-5. 
de 1985, ao recomendar que Os governos devem desenvolver, reforçar ou manter uma política de proteção ao consumidor; e em outra passagem: Os governos devem prover ou manter uma infra-estrutura adequada para desenvolver, implementar e orientar a política de proteção ao consumidor.

A segunda recomendação materializou-se, com muita ênfase e efetividade entre nós, com a edição do Código de Defesa do Consumidor (lei n. 8.078, de 11-9-1990), contendo ampla disciplina quanto aos direitos gerais e básicos do consumidor, relação de consumo, proteção contratual, responsabilidade civil do fornecedor, estilos de publicidade, defesa administrativa e processual.

\subsubsection{Dos mecanismos administrativos}

Aqui, a função do Estadoadministrador, atividade primária, que se consubstancia no poder-dever de gestão da coisa pública, como munus publicum que lhe é próprio, independentemente de provocação do súdito interessado. ${ }^{10}$ Nesse sentido, pode-se mais uma vez invocar a frase já tantas vezes repetida de que administrar é aplicar a lei de oficio."
Como ocorreu na França, desde os primórdios do século passado, a primeira preocupação do Estado em tema de proteção ao consumidor deve ser de conteúdo pedagógico, no sentido de informá-lo e educá-lo para enfrentar a batalha do consumo, satisfazendo as suas necessidades dirigidas para uma melhor qualidade de vida e precavendose contra os males do consumismo e contra os desequilíbrios contratuais tão freqüentes nas relações de consumo. Esses princípios, propostos por John Kennedy perante o Congresso dos Estados Unidos em 1962, foram admitidos pela Comissão de Direitos Humanos das Nações Unidas, em sua $29^{a}$ Sessão, realizada em Genebra, em 1973, como direitos fundamentais e universais do consumidor. ${ }^{12}$ De tão grande relevância são consideradas a informação e a educação dos consumidores em Portugal e Espanha, de tal modo que nas suas leis específicas introduziram esse tema como matéria obrigatória em programas oficiais de ensino público (art. $8^{\circ}$ da lei portuguesa n. $29 / 81$ e art. 18 , n. 2, da lei espanhola n. 26/84). E, nos Estados Unidos, desde há algum tempo, são ministrados programas educacionais para treinamento de pessoal especializado na

10 Rodolfo de Camargo Mancuso, Comentários ao Código de Proteção do Consumidor, São Paulo, Saraiva, 1991, p. 271-2.

11 Cf. Miguel Seabra Fagundes, em sua conhecida monografia $O$ controle dos atos administrativos pelo Poder Judiciário.

12 Luiz Otávio de Oliveira Amaral, História e fundamentos do direito do consumidor, $R T$, 648:32. 
matéria consumer affair, bem como para educar e orientar o consumidor, pelo Consumer's Education Office.

Outros organismos de proteção ao consumidor têm surgido no concerto internacional. Dentre tais, podem ser arrolados, a título de exemplificação: a Carta do Consumidor; a Federal Trade Commission, órgão máximo do sistema federal; a Food and Drug Administration; o Attorney General e a Commission criada pelo Federal Consumer Product Safeties Acts, nos Estados Unidos; Ombudsman do consumidor, na Suécia e em outros países escandinavos; o Institut National de la Consommation, na França; o Instituto National del Consumidor, no México; a Prokuratura nos ordenamentos socialistas; o Instituto Nacional de Defesa do Consumidor, em Portugal; o Instituto Nacional del Consumo, na Espanha, etc.

No Brasil, o primeiro diploma diretamente destinado à tutela administrativa e também de natureza pedagógica no que diz com a atividade e relações de consumo é o decreto $n$. 9.469/85, editado coevamente à lei da Ação Civil Pública e alterado pelo decreto n. 94.508/87. O primeiro desses diplomas normativos criou o Conselho Nacional de Defesa do Consumidor CNDC, como órgão de assessoria à Presidência da República, para a formulação e condução da política nacional de defesa do consumidor, com competência específica para promover e incentivar medidas e campanhas de formação e informação do consumidor, quanto à escolha do produto adequado à satisfação de suas necessidades e compatível com a sua capacidade econômica, visando extrair da relação de consumo os melhores benefícios possíveis, disposição essa hoje presente também na lei específica ( $\operatorname{art} .4^{\circ}, \mathrm{IV}$, do Código de Defesa do Consumidor).

Objetivava ainda o diploma legal referido a formulação de uma política global de consumo, a criação, a transformação e a coordenação dos órgãos fiscalizadores em todos os níveis da esfera administrativa, celebrar convênios com entidades nacionais e estrangeiras dedicadas à defesa do consumidor; solicitar a abertura de inquérito policial à Polícia Federal, representar perante o Ministério Público a ocorrência de lesões aos direitos do consumidor e outras atribuições várias. O referido órgão foi atingido pela Reforma Administrativa no âmbito federal, sendo substituído por outro.

$\mathrm{Na}$ esfera administrativa do Governo da União convivem cerca de trinta e dois órgãos dedicados direta ou indiretamente à tutela dos interesses do consumidor, de modo a se constatar, às vezes, verdadeiro tumulto administrativo ou paralelismo burocrático capaz de entravar a dinâmica dos serviços. Dentre os principais órgãos podem ser mencionados o Departamento Nacional de Defesa do Consumidor, o Conselho Administrativo de Defesa Econômica (CADE), a Associação Brasileira de Normas Técnicas, o Conselho Nacional 
de Metrologia, Normalização e Qualidade Industrial (Conmetro), a Superintendência Nacional do Abastecimento (SUNAB), a Companhia Brasileira de Alimentos (Cobal), etc.

$\mathrm{Na}$ esfera estadual, predominam geralmente os PROCONs, podendo ser criados outros órgãos protetivos dos consumidores locais, segundo estabeleçam os critérios políticos de cada unidade federada.

Restam ser mencionadas as associações de consumidores, como entidades, agora incentivadas pela lei atual (arts. $4^{\circ}$, II, $a$, e $5^{\circ}, \mathrm{V}$, do Código de Defesa do Consumidor), que poderão constituir-se sob o modelo de associações civis, na forma da lei civil (arts. 53 a 61, do Código Civil atual), mediante registro de seus atos constitutivos no Ofício do Registro Civil das Pessoas Jurídicas.

\section{DOS MECANISMOS NO ÂMBITO DO PODER JUDICIÁRIO PARA A TUTELA DO CONSUMIDOR}

Aqui se manifesta a função do Estado-juiz, mediante a qual se instituem os mais completos e eficazes instrumentos de tutela dos interesses ou direitos do consumidor, exercidos pelo Poder Judiciário. Essa é a clássica divisão de funções públicas do Estado, de legislar, de administrar e de judicar, espraia-se pelas diversas sedes da codificação especial. Nesta última função, o Estado não age esponta- neamente como nas demais, uma vez que a atuação jurisdicional está sujeita ao princípio geral ne procedat iudex ex officio, consagrado no ordenamento processual geral (art. $2^{\circ}$ do CPC).

Outra singularidade a ser ressaltada é que na codificação especial dá-se predominante relevo à defesa coletiva do consumidor, como salienta enfaticamente o art. 81 e seu parágrafo único, certamente por compreender o legislador que a defesa dos direitos individuais do consumidor, envolvendo conflitos intersubjetivos (v.g., Tício versus Caio), já se encontra naturalmente regulada pela lei geral, o Código de Processo Civil, e em certas leis extravagantes, como as referentes às locações de imóveis urbanos (lei n. 8.245/91), aos alimentos (lei n. 5.478/68), aos direitos autorais (lei n. 5.988/73), à proteção da criança e do adolescente, denominada Estatuto da Criança e do Adolescente (lei n. 8.069/90) e outras.

A doutrina prevalente no Código de Defesa do Consumidor funda-se nitidamente na idéia de coletivização da defesa dos direitos que contemporaneamente vem suplantando a concepção individual fundada no direito subjetivo. Manifestações dessa tendência, que abundam nos sistemas jurídicos alienígenas, também já se vinham esboçando no direito pátrio, como sóe acontecer com as experiências da ação popular (lei n. 4.717/ 65); da ação civil pública (lei n. 7.347/ 85); das ações coletivas, tais como o dissídio coletivo (arts. 856 e 857 da 
CLT); e da ação de cumprimento (art. 872, parágrafo único, da CLT), na área trabalhista, exercidas pelo sindicato; do mandado de segurança coletivo (art. $5^{\circ}$, LXX, da CF); e do mandado de injunção (art. $5^{\circ}$, LXXI, da CF).

Em tema de mecanismos judiciários, para implementar a efetiva tutela dos direitos do consumidor, caberia ao legislador nacional a escolha de uma entre três opções: criar modelo próprio, filiar-se ao modelo romano-germânico ou ao sistema da common law, já que o outro sistema, o socialista, tem menor identidade jurídica, social e política com o nosso.

O modelo da common law, que envolve o sistema inglês e o norteamericano, ampara-se fundamentalmente na equity, com antecedentes no Bill of Peace do século XVII. Transfunde-se na relator action da experiência inglesa e australiana e na class action do modelo norteamericano, extensíveis também a outros interesses difusos que não os do consumidor. Funda-se em sistema de ações, que, embora peculiar à família common law, é habitualmente representado pelo aforismo construído pelos romanistas ubi actio, ibi ius.

O paradigma europeu-continental, fundado em sistema de direitos e não de ações, que se expressa pelo aforismo ubi ius, ibi actio, é fonte do nosso sistema e por isso com ele guarda maior identidade.

Na elaboração do Código de Defesa do Consumidor, o legislador não criou nem modelo próprio, nem modelo novo. Preferiu recolher as experiências ora do sistema europeu-continental, ora do norte-americano. Assim é que as três ações coletivas de que trata o art. 81, parágrafo único, do Código pátrio assemelham-se, em sua estrutura, à action civile colletive do sistema francês, criada com a Lei Royer (lei n. 73-1193, de 27-12-1973), e à ação coletiva do sistema alemão.

Por outro lado, no que diz com o tipo de tutela produzida, assemelhamse as nossas ações à class action norte-americana. Com efeito, a ação coletiva para a defesa dos interesses difusos (inc. I do art. 81) assemelha-se à true class action; a mesma ação para a defesa de interesses coletivos (inc. II) assemelha-se à hybrid class action; e a ação do mesmo tipo para a tutela dos direitos individuais homogêneos (inc. III) assemelha-se à spurious class action. ${ }^{13}$

Aqui não se pode deixar de registrar que, enquanto nos Estados Unidos a class action pode ser proposta por um ou mais membros da classe, independentemente da organização do grupo

13 Sobre o assunto, v. José Rogério Cruz e Tucci, Class action, cit., p.21; Ada Pellegrini Grinover, A tutela jurisdicional dos interesses difusos no direito comparado, in A tutela dos interesses difusos, São Paulo, Max Limonad, 1984, p. 79-80; Pierre Godé, Dictionnaire juridique - consommation, Paris, Dalloz, 1983, p. 18-21. 
como pessoa jurídica, bastando a prova do interesse comum apreciada livremente pelo juiz, as ações coletivas dos sistemas alemão, francês e brasileiro só podem ser promovidas por associações de consumidores juridicamente constituídas ou pelas pessoas do direito público indicadas no art. 82.

\subsection{Do acesso do consumidor à justiça}

Não obstante os postulados ou princípios do livre acesso aos órgãos judiciários, da inafastabilidade do processo judicial para o deslinde dos litígios, do devido processo legal e da gratuidade de justiça aos necessitados, consagrados genérica ou especificamente na Carta Política brasileira (art. $5^{\circ}$ ), nem sempre os consumidores conseguem chegar às portas dos tribunais para obter a tutela dos seus direitos.

O enfoque da expressão hoje tão em voga acesso à Justiça ${ }^{14}$ supõe a persecução de um duplo escopo, que se consubstancia no acesso aos procedimentos adequados à vindicação dos direitos e na solução das desavenças sob os auspícios do Estado. $\mathrm{O}$ primeiro constitui indubitavelmente pressuposto do segundo, que se identifica na justa solução dos litígios, um dos escopos político-sociais do Welfare
State. Assim, o acesso ao Poder Judiciário diz prioritariamente com o primeiro objetivo, mas, ao persegui-lo, não se pode perder de vista o segundo, que é o desiderato final.

Esse primeiro passo para o alcance do deslinde do litígio é que deve ser indistintamente franqueado à população do Estado, na qual se insere o indimensionável contingente dos consumidores e para os quais o acesso $\grave{a}$ Justiça constitui direito básico (art. $6^{\circ}$, VII, do CDC).

O projeto de acesso à Justiça deve estar armado de mecanismos capazes de superar as dificuldades naturais e ínsitas à própria individualidade do consumidor, qual a de ser solitário, sempre desarmado de poder político e econômico e bloqueado por fatores psicológicos que lhe tolhem a iniciativa. Esses fatores negativos podem ser ainda agravados por carências culturais ou por desconhecimento técnico de problemas com os produtos indispensáveis à sua sobrevivência, de modo a infundirem no espírito do consumidor verdadeiro sentimento de inferioridade em relação ao produtor.

Além desses, há ainda que se atentar para as questões do desinteresse do pleito pela exigüidade da lesão, os "mistérios" do processo na ótica laica, a lentidão da Justiça, que

14 Sobre o tema "acesso à justiça", v. Mauro Cappelletti e Bryant Garth, Acesso à justiça, trad. Port. de Ellen Gracie Northfleet, Porto Alegre, Sérgio A. Fabris, Editor, 1988, passim; Stiglitz, Contratos por adhesión, cláusulas abusivas y protección al consumidor, Buenos Aires, Depalma, 1985, p. 251-65. 
ainda não se desvencilhou completamente das amarras do princípio dispositivo imperante nos séculos XVIII e XIX, bem como a escassez de recursos econômicos para o enfrentamento das despesas forenses.

O laissez-faire que caracterizou o vasto período individualista dos últimos séculos vem sendo superado, com maior velocidade no pós-guerra 19391945, a partir dos novos conceitos acerca dos direitos humanos e do reconhecimento da sobrelevação dos direitos sociais em relação aos individuais, que se encontram inscritos em todas as declarações de direitos e nos pórticos das Cartas Políticas, dentre as quais não se pode deixar de referir a francesa de 1946 e a brasileira de 1988.

$\mathrm{O}$ direito de acesso à Justiça modernamente erige-se em fenômeno sócio-político que se coloca como pressuposto necessário à universalização da tutela jurisdicional, a que o Estado moderno persegue e que está presente não só nas preocupações dos cientistas políticos, mas também nas proposições dos processualistas. ${ }^{15}$

O enfoque de tais preocupações há muito deixou de ser exclusivo do direito individual, centrado no direito subjetivo clássico, para alcançar os direitos ou interesses difusos e coletivos. Nessa idéia de coletivização do acesso à
Justiça incluem-se os direitos do consumidor, de tal modo que os entraves com que este se deparava, para a efetivação desses direitos, vêm sendo amenizados mediante a criação de novos mecanismos postos à sua disposição, tais como a gratuidade de justiça, a instituição de órgãos judiciários mais dinâmicos como os Juizados Especiais (lei n. 9.099/95); a flexibilidade dos procedimentos; a legitimação ativa de associações de consumidores; a inversão do ônus da prova; o redimensionamento do instituto da coisa julgada, etc.

Mas todos esses fatores concebidos pela doutrina em geral para superar as ditas dificuldades do consumidor no pleito dos seus direitos, poderão, no Brasil, lamentavelmente esbarrar nos formidáveis problemas que o Estado enfrenta com a administração da Justiça, cuja organização e praxes judiciárias se encontram secularmente plantadas, sem melhorias capazes de acompanhar a evolução dos tempos, com seus estilos, modismos, vícios e cacoetes cartoriais, de tal modo a causar certo cansaço, justificável desânimo, senão ameaçadora desesperança para as pessoas mais desarmadas de poder exercitarem seus direitos.

Não basta o puro e simples acesso à Justiça e a instituição de ações

$15 \mathrm{O}$ fenômeno diz estreitamente com a efetividade do processo. Sobre o assunto, v. Cândido Rangel Dinamarco, $A$ instrumentalidade do processo, n. 36.1, 36.2 e 36.3, p. 391 434; v. também Adolfo Gelsi Bidart, Proceso y época de cambio, Revista de Estudios Procesuales, Rosario, Centro de Estudios Procesuales de Rosario, 1974, v. 19. 
típicas e as outras tantas reformulações realizadas pelo Código de Defesa do Consumidor, mas é preciso também que se criem juízos rápidos, aumentando o número de juizados especiais ao lado de um esforço global de conscientização dos espíritos para que se assimile a necessidade de atuação célere da Justiça, como a última trincheira onde se albergam as esperanças do homem comum.

Exemplos inequívocos dessa predisposição de espíritos hão de ser colhidos no continente europeu, já no início do presente século. Informa-nos Adolf Wach, com a sua autoridade, que na Alemanha, logo após a edição da $Z P O$, cerca de $30 \%$ dos processos perante os tribunais de primeira instância, os Amtsgerichte e os Landsgerichte, duraram menos de três meses; quase $60 \%$ com solução em menos de seis meses; e quase $10 \%$ resolvidos em menos de um ano. ${ }^{16}$

Fenômeno semelhante ocorreu na Áustria, após a entrada em vigor do Código de F. Klein, em 1898. Segundo a mesma fonte, cerca de $40 \%$ dos processos foram solucionados em menos de um mês, mais de $50 \%$ em torno de seis meses, e em prazo superior a um ano apenas uma percentagem entre $0,4 \%$ e $1,2 \% .^{17}$

Esses fatos deveram-se à estreita adequação da organização judiciária dos dois referidos Estados, que consagrava a colegialidade dos seus tribunais para fazer atuar o processo oral e concentrado, admitido nas suas respectivas codificações processuais.

No Brasil, o problema da morosidade forense vem sendo, ainda que modestamente, solucionado através de dois expedientes governamentais de ordem legislativa que já contam com previsão legal expressa: a criação de novos juizados especiais e de varas especializadas, além dos já existentes, para solucionar litígios de consumo, para o que já existe autorização constitucional que institui a competência genérica, da União, dos Estados e dos Territórios, para a criação de juizados especiais, providos por juízes togados e leigos, competentes para a conciliação, julgamento e execução de causas cíveis de menor complexidade.

Quanto aos primeiros, já existe bom número em funcionamento na Justiça dos Estados e também na Justiça Federal, com resultados muito satisfatórios. Tantos outros quantos necessários podem ser criados pela União, Estados e Distritos Federal, cujo procedimento deve orientar-se pelos canais da oralidade, da simplicidade, da informalidade, da economia, da celeridade e da conciliação das partes desavindas, segundo as expressas disposições da lei especial (art. $2^{\circ}$, da lei n. 9.099, de 26.09.1995).

16 Mauro Cappelletti, Procédure orale et procédure écrite, Milano, Giuffre, 1971, p. 60 e 62. 17 Mauro Cappelletti, Procédure, cit., p. 63. 
Em tal tipo de procedimento, o juiz poderá contar com a colaboração de conciliadores e juizes leigos, ${ }^{18}$ (lei $n$. $9.099 / 95$, arts. $5^{\circ}, 6^{\circ}$ e $7^{\circ}$ ), no qual estão praticamente contemplados todos os mecanismos de que dispunham os Códigos da Áustria e da Alemanha, no início do século, e que os levaram aos sucessos acima relatados.

A Constituição atual (art. 98, I) permite que tais órgãos sejam singulares ou coletivos, competentes para a conciliação das partes e que atuem mediante o procedimento oral e sumário, rematando por adotar o princípio do único grau de jurisdição para o julgamento de recursos, caso em que o Juízo deverá ser necessariamente colegiado na forma disposta no artigo $41, \S 1^{\circ}$, da lei . 9.099/95.

Com tais providências, que já estão sendo tomadas pelas autoridades responsáveis, vem o Código de Defesa do Consumidor obtendo razoáveis condições de aplicabilidade e alcançando os escopos para os quais foi criado.

\subsection{Dos mecanismos típicos e atípicos de tutela jurisdicional do consumidor}

Para tutelar os direitos ou interesses do consumidor, o legislador especial foi colher elementos nos paradigmas oferecidos pelos ordenamentos jurídicos vinculados às famílias civil law e common law, elaborando, nesse mister, um verdadeiro trabalho de síntese em que conjugou os modelos do sistema romano-germânico, retirados especialmente das experiências francesa e alemã, com os do sistema anglo-americano, notadamente extraídos deste último modelo, como já foi referido acima (item 3.1).

Passemos, pois, à análise particularizada dos mecanismos jurisdicionais coletivos e individuais adequados para tutelar os interesses ou direitos dos consumidores na área do processo civil.

\subsubsection{Da tutela coletiva}

No âmbito do processo de conhecimento, criou o legislador cinco ações coletivas em prol da proteção do consumidor que podem ser consideradas ações típicas. Tais são as três ações coletivas do art. 81, parágrafo único, I, II e III, a ação de responsabilidade civil do fornecedor de produtos e serviços dos arts. 101 e 102, todos do Código de Proteção e Defesa do Consumidor, e a ação civil pública disciplinada pela lei n. 7.347/85.

A ação civil coletiva, de que trata o art. 81, parágrafo único, I, criada à semelhança da true class action norteamericana, constitui ação típica, destinada à tutela dos interesses ou direitos difusos, como tais entendidos os de natureza transindividual ou metaindividual, indivisíveis, de que

18 Cândido Rangel Dinamarco, Manual das pequenas causas, São Paulo, Revista dos Tribunais, 1986, n.5-9, p. 9-11. 
sejam titulares pessoas indeterminadas e indetermináveis, ligadas por circunstância de fato.

A tutela produzida por este tipo de mecanismo processual é de caráter inibitório da materialização da ação danosa do demandado, quando esta ainda não se tiver iniciado, ou da sua suspensão, quando parte do resultado danoso já se tiver produzido. Porém, no caso de seu objeto constituir o cumprimento de obrigação de fazer ou não fazer, dois outros tipos de tutela podem-se produzir segundo as hipóteses veiculadas pelo art. 84 e seus $\S \S 1^{\circ} \mathrm{e}$ $2^{\circ}:$ a) a tutela será reparatória, quando se cuidar de obrigação personalíssima e o juiz impuser ao obrigado o cumprimento da prestação in natura, ou, na impossibilidade desta, a sua conversão em perdas e danos, ou, quando não for personalíssima, o seu cumprimento através de terceiro, às custas do obrigado; b) a tutela será sancionatória, no caso do cumprimento da prestação pelo equivalente ser cumulado com a pena pecuniária (astreintes) prevista nos arts. $287 \mathrm{e}$ 644-645 do Código de Processo Civil.

A eficácia erga omnes, que the atribui a lei (art. 103, I, do CDC), projeta-se por amplo espectro, em face da indimensionável multiplicidade de sujeitos que venham a ter seus interesses protegidos. Consulta, pois, um dado subjetivo. Tem, no entanto, sua ampliação subjetiva máxima obviamente limitada à totalidade da população estatal, pelo simples fato de que a jurisdição só é eficaz, em regra, aos súditos do Estado e aos estrangeiros que contingencialmente gozem da sua proteção. Por outro lado, a limitação mínima da sua abrangência diz com um dado objetivo, pois restará subordinada a uma circunstância de fato espacial que dimensionará o prejuízo que determinado produto ou serviço venha a causar à saúde, ao bem-estar, etc., da população de certa cidade, ou região, ou país.

Este o sentido do efeito erga omnes de que se ocupa o art. 103, I, e que se opera secundum eventum litis pela circunstância de que, no caso de improcedência da ação, por insuficiência de prova, pode ela ser renovada por qualquer interessado, mediante nova prova. Esta é uma conotação excepcional, criada pela lei especial, que distoa da eficácia da coisa julgada, no processo comum.

A ação civil coletiva de que trata o art. 81, parágrafo único II, criada à semelhança da hybrid class action norte-americana, é outra ação típica que se dirige à proteção dos interesses ou direitos coletivos, definidos legalmente como tais os transindividuais de natureza indivisível, de que seja titular grupo, categoria ou classe de pessoas ligadas entre si ou com a parte contrária por relação jurídica base.

A tutela por esta produzida não difere, por sua natureza, da anterior, pois é também meramente inibitória do ato antijurídico, se o prejuízo ao direito do consumidor ainda não se tiver materializado. 
Porém, nas hipóteses reguladas pelo art. 84 e $\S \S 1^{\circ}$ e $2^{\circ}$, a ação civil coletiva, neste passo analisada, produzirá tutela do tipo reparatório, ou, ainda, tutela sancionatória, nos mesmos casos examinados acima, para a ação coletiva na defesa de direitos ou interesses difusos. Aqui, como na hipótese anteriormente tratada, a aplicação da sanção ao demandado, sob a modalidade de astreintes, poderá ser feita ex officio pelo juiz, quando for relevante o fundamento da demanda e houver justificado receio de ineficácia do provimento final (art. 84, $\S \S 3^{\circ} \mathrm{e} 4^{\circ}$ do $(D C)$, casos em que a lei especial derrogou o princípio da iniciativa particular do ne procedat iudex ex officio, a que está sujeita essa providência perante a lei processual comum (arts. $2^{\circ}$ e 287 do CPC).

A eficácia ultra partes proclamada pelo Código de Defesa do Consumidor (art. 103, II) para este tipo de tutela jurisdicional, transcende aos intervenientes na demanda judicial, mas limita-se ao grupo, categoria ou classe de indivíduos abrangidos pela relação iurídica base que os vincula entre si, ativa ou passivamente, podendo-se espelhar tal perspectiva na hipótese, $v$. g., do fornecimento de produtos ou serviços, cujas relações de consumo estejam subordinadas a certas condições estipuladas em convenção coletiva de consumo firmada entre entidades representativas de fornecedores e consumidores, a teor do art. 107 do Código de Defesa do Consumidor.
Não há outros dados objetivos para limitá-la, senão os contornos territoriais em que exerce a jurisdição estatal e o elemento qualitativo do prejuízo dos consumidores por ela alcançados.

A ação civil coletiva, de que trata o art. 81, parágrafo único, III, criada à semelhança da spurious class action, a terceira ação típica, destina-se à proteção dos chamados interesses ou direitos individuais homogêneos, como tais entendidos os que têm origem comum. Os direitos lesados não se enquadram entre os difusos, nem os seus titulares estão vinculados entre si por uma relação jurídica básica, podendo, por isso, ser identificados à medida que ingressam no feito, como litisconsortes, em decorrência da ciência do processo especial pela publicação de edital no órgão oficial ou pelos meios de comunicação social praticados entre os consumidores (art. 94 do CDC).

Neste caso, a tutela dos direitos ou interesses do consumidor é essencialmente reparatória, quando se cuidar da indenização de danos patrimoniais sofridos individualmente pelo consumidor. Mas poderá ser de natureza sancionatória, quando se tratar da proteção de direitos ou interesses tuteláveis pela ação civil pública de que trata a Lei n. 7.347/85 (art. 99 e parágrafo único do $\mathrm{CDC}$ ), ou quando decorrer um ano da sentença condenatória sem que haja habilitação de interessados em número compatível com a gravidade do dano (art. 100 e parágrafo único do $\mathrm{CDC}$ ). Nestes dois 
últimos casos, o valor da indenização não se destinará diretamente aos prejudicados, mas será recolhido ao Fundo criado pela Lei n. 7.347/85 e regulamentado pelo Decreto n. $92.302 /$ 86 , conforme dispõem os arts. 99 e 100 e seus respectivos parágrafos únicos do Código de Defesa do Consumidor.

No caso de procedência da ação proposta, a sentença produzirá efeitos erga omnes, para beneficiar todas as vítimas e seus sucessores (art. 103, III do $\mathrm{CDC}$ ), mesmo que não tenham participado do processo. Porém, se a ação for julgada improcedente, os interessados que não se tenham integrado ao processo especial, como litisconsortes, poderão intentar ação de indenização a título individual $\left(\operatorname{art.} 103, \S 2^{\circ}\right.$ ).

A última ação de conhecimento, típica, prevista pelo Código de Proteção e Defesa do Consumidor, é a ação de responsabilidade civil contra o fornecedor de produtos e serviços, fundada genericamente na regra do art. $6^{\circ}$, VI, e especificamente na dos arts. $101 \mathrm{e}$ 102, que pode ser individual ou coletiva. Constitui o mecanismo processual adequado a ensejar o ressarcimento dos prejuízos sofridos pelo consumidor contra o fornecedor e os demais coresponsáveis pelo fato do produto e do serviço (arts. 12 a 17 do CDC), ocorrendo tal responsabilidade independentemente de culpa, salvo os casos indicados no $\S 3^{\circ}$ do artigo 12 .

$\mathrm{O}$ legislador omitiu-se quanto à regulamentação da ação de responsabilidade do produtor pelos vícios de qualidade ou de quantidade do produto ou do serviço, também chamados vícios de inadequação, que os tornem inadequados ao uso e consumo (arts. 18 a 23). Apesar disso, a lacuna poderá ser suprida pelos instrumentos processuais atípicos oferecidos pela lei processual comum, aplicável subsidiariamente, segundo o artigo 90, do CDC, de que trataremos logo a seguir, como também em face da amplitude da regra do art. 83, ao dispor que "para a defesa dos direitos e interesses protegidos por este Código são admissiveis todas as espécies de ações capazes de propiciar sua adequada e efetiva tutela". Ademais, poderá a jurisprudência, mediante construção própria, oferecer seus suprimentos, ao se defrontar com a aplicação dinâmica desse microssistema.

Tais ações têm sua origem em construções magistrais da jurisprudência anglo-saxônica, fundadas no dever de diligência do fabricante (duty of care), e da jurisprudência alemã, fundadas na culpa organizativa da empresa (Organisationsverschuld), tendo como caso padrão a sentença do Supremo Tribunal alemão (Bundesgerichtshof), no famoso caso da "peste dos frangos" (Hühnerpest Urteil), quando o tema da responsabilidade civil do fabricante adquiriu maioridade no direito tedesco. No sistema anglo-saxônico, há precedentes firmes, no âmbito do direito inglês, a partir do caso Longmeid v. Holliday, em 1851, mas a evolução jurisprudencial 
culminou com a sentença proferida pela House of Lords, no caso Donoghue v. Stevenson, em 1932, enquanto, no campo do direito norte-americano, são conhecidos os casos Thomas $v$. Winchester, em 1852, este como leading case, e Mac Pherson v. Buick Motor Co., em 1916, dentre os principais. ${ }^{19}$

A ação de responsabilidade civil é de natureza ressarcitória, razão por que produz tutela essencialmente reparatória.

Por fim, a última ação típica é a ação civil pública regulada pela lei $\mathrm{n}$. $7.347 / 85$. Embora ela não integre o elenco dos arts. 81 e 101 do Código de Defesa do Consumidor, endereça-se à defesa de determinados direitos ou interesses do consumidor, não só em razão da remissão feita pelo art. 90 dessa codificação especial, como também por força de disposição expressa contida no art. $1^{\circ}$, II da lei $n$. $7.347 / 85$, que a disciplina.

Parece não restar dúvida de que a ação civil pública pode ser utilizada, além dos casos específicos para os quais está diretamente vocacionada (art. $1^{\circ}$, I, III e IV da lei n. 7.347/85), também para a defesa dos interesses ou direitos difusos e coletivos do consumidor, seja em razão da remissão feita pelo art. 90 do CDC, seja por força da disposição expressa contida no art. $1^{\circ}$, II, daquela lei especial. É que esses direitos ou interesses do consumidor são por natureza metaindividuais e dizem respeito, os difusos, ao interesse geral, pertinentes à coletividade inteira em que o prejuízo de um implica oneração de todos, indivisivelmente, ${ }^{20}$ ou dizem, os coletivos, com o interesse comum, também indivisível, de uma parcela ponderável da comunidade, caracterizada por um mínimo de organização, pela afetação a um grupo determinado ou determinável e que se encontrem atrelados por um vínculo iurídico base. ${ }^{21}$

A assertiva ainda se embasa no fato de que a tutela que se produz na atividade jurisdicional para a defesa dos interesses difusos e coletivos do consumidor é de natureza inibitória, impeditiva ou sustadora do fato ou ato danoso à coletividade, e a eventual tutela reparatória das perdas e danos decorrentes da impossibilidade do cumprimento da prestação específica (art. 84 e parágrafos do CDC), deve ser recolhida ao fundo criado pela lei $n$. 7.347/85 (art. 13), em face da aplicação

19 Neste sentido consultem-se os estudos magníficos de Luiz Gastão Paes de Barros Leães em sua tese intitulada $A$ responsabilidade do fabricante pelo fato do produto, cit., p. 31-82. 20 José Carlos Barbosa Moreira, A legitimação para defesa dos interesses difusos no direito brasileiro, in Temas de direito processual, terceira série, São Paulo, Saraiva, 1984, p. 183-92.

21 Rodolfo de Camargo Mancuso, Interesses difusos; conceito e legitimação para agir, São Paulo, Revista dos Tribunais, 1988, p. 44-5. 
subsidiária dessa lei especial aos interesses e direitos do consumidor, como dispõe o citado artigo 90 da lei consumerista, remissão essa estrategicamente colocada pelo legislador ao final do capítulo I, do título III que disciplina as defesas de interesses difusos e coletivos contidos na relação de consumo.

Tais conotações têm o condão de conformar a defesa desses dois tipos de interesses do consumidor à vocação da ação civil pública. A opção entre esta e as ações coletivas dos incisos I e II do art. 81 do CDC dependerá, na aplicação casuística dessa codificação, das contingências de fato que a hipótese apresentar, escolhendo-se dentre tais instrumentos o que parecer mais adequado| à proteção reclamada, segundo se infere da regra do art. 83 desse microssistema.

Não parece estar a ação civil pública vocacionada para a defesa dos interesses individuais homogêneos, onde a tutela pretendida é primordialmente reparatória, salvo nas hipóteses, certamente raras, de pretensões fundadas em obrigações de fazer ou não fazer, em que a tutela é sancionatória na primeira e inibitória na segunda.

Com maiores razões, a ação civil pública não é instrumento hábil para ação de responsabilidade civil contra o fornecedor de produtos e serviços de que cuida o art. 101, por ser essencialmente ressarcitória, não se coadunando com o desiderato final daquela que reverte para o fundo do artigo 13, da lei n. 7.347/85. Não parece incompatível, porém, com a ação cominatória contra o Poder Público de que trata o artigo 102, da lei consumerista.

A eficácia da sentença na ação civil pública, que é secundum eventum litis, será erga omnes, salvo se julgada improcedente por deficiência de provas (art. 18 da lei n. 7.347/85, c/c o art. 103, I, do CDC), mas será ultra partes, limitada ao grupo, categoria ou classe, exceto na hipótese antes aventada.

\subsubsection{Da tutela individual}

$\mathrm{Na}$ defesa dos interesses ou direitos do consumidor os mecanismos processuais utilizados são, em regra, coletivos. As ações coletivas caracterizam-se subjetivamente pela maior potencialidade de proteção desses interesses por englobar os legitimados ativos referidos no artigo 82 , e, objetivamente, pela maior ou menor coletivização ou fluidez do bem da vida pretendido pelos titulares desses interesses tutelados. São, assim, as ações coletivas, mais adequadas para o mister, porque suprem as insufi-ciências de ordem econômica, cultural e psíquica do consumidor individual e do seu minúsculo interesse no contraste com o aparato técnico e o suporte econômico dos outros sujeitos que se postam no outro pólo da relação de consumo: o fabricante, o produtor ou o comerciante.

$\mathrm{Na}$ gama dos mecanismos típicos para a tutela do consumidor, resta a possibilidade de ser individual a ação 
de responsabilidade pelo fato do produto contra o fornecedor de produtos e serviços, de que trata o artigo 101 e incisos, em face da alternativa oferecida pelo artigo 81. Pode a mesma ação ser meramente individual, quando promovida por qualquer consumidor isoladamente, ou individual plúrima, quando promovida por grupo informal de consumidores individuais, em litisconsórcio ativo facultativo, que pode ser inicial ou ulterior, segundo o cúmulo subjetivo se forme $a b$ initio ou venha a constituir-se após a instauração do processo. Essa a única defesa individual típica, em tema de proteção do consumidor, prevista no art. 81 do CDC.

No entanto, há uma plêiade de tutelas individuais atípicas que são colocadas à disposição do consumidor através do processo comum regulado pelo Código do Processo Civil, por força mesmo do disposto no art. 83 da lei consumerista, que diz o óbvio, porquanto é princípio geral que toda a conduta humana é permitida se não expressamente vedada por lei, conforme dispõe o artigo $5^{\circ}$, II, da Constituição.

De qualquer modo, o legislador houve por bem assim dispor, o que significa dizer que o consumidor poderá também dispor de todos os instrumentos definidos no processo comum para a tutela dos seus direitos, podendo valerse do processo comum ordinário ou sumário (CPC, art. 272), que no caso couber, a teor do artigo 90 da lei consumerista. São as ações atípicas que vêm completar o elenco de mecanismos processuais ao alcance do consumidor.

Há no processo pátrio, além dos mecanismos pertinentes ao procedimento comum, um outro de procedimento especial, chamado Juizado Especial, já referido item 3.1 supra, criado pela lei n. 9.099/95, que implementa outro modo de proceder capaz de empreender grande rapidez na solução de certos conflitos de natureza patrimonial que se enquadrem no conceito de causas de menor complexidade, a teor do artigo 98, I, da Constituição Federal, cuja aferição se realiza ratione materiae e ratione valoris.

As causas que se resolvem através desse procedimento especial podem ensejar aos que a ele recorrem uma tutela condenatória decorrente de sentença condenatória, cujo valor não exceda a quarenta (40) vezes o salário mínimo; que julgar as causas enumeradas no artigo 275, II, do CPC; a ação de despejo para uso próprio; e as ações prossessórias sobre bens imóveis de valor não superior a 40 salários mínimos; e bem assim as execuções dos seus julgados e as de títulos extrajudiciais de valor até 40 salários mínimos, segundo dispõe o artigo $3^{\circ}$, da mencionada lei n. 9.099/95.

O processo obedece à preocupação da lei especial, centrada na economia e na celeridade, mas esses resultados se obtêm pelo procedimento oral e de seus afluentes ou princípios satélites, como os da imediatidade, concentração e irrecorribilidade das interlocutórias em 
separado, conforme a pregação de Chiovenda. ${ }^{22}$

O que se percebe, todavia, da análise conjunta das duas leis especiais, o Código de Defesa do Consumidor e a Lei dos Juizados Especiais é que este último procedimento especial não se ajusta às ações coletivas, mas tãosomente às ações individuais para a defesa do consumidor.

Além dessas, poderá ainda o consumidor dispor de outra ação atípica para o sistema pátrio, mas muito em voga nos sistemas de proteção ao consumidor dos países pertencentes à Comunidade Econômica Européia, que através de sua Carta do Consumidor recomenda aos Estados-Membros que a integram que instituam o juizo arbitral como mecanismo processual hábil para resolver os litígios entre fornecedores e consumidores. ${ }^{23} \mathrm{Tal}$ mecanismo pode ser instituído entre nós, mediante introdução de cláusula compromissória nas convenções coletivas de consumo previstas no art. 107, do CDC. Embora seja um modo para solução dos litígios pouco usado no Brasil, nada obsta que se constitua o iuizo arbitral mais um mecanismo atípico em defesa dos direitos do consumidor, que no sistema pátrio está regulado pela lei n. 9.307/96.

\subsubsection{Da tutela preventiva}

Além das tutelas definitivas conferidas pela lei especial e pela legislação comum para a defesa de interesses ou direitos do consumidor acima examinadas, a codificação de consumo contempla alguns procedimentos preparatórios e assecuratórios desses direitos.

A medida já contemplada pela lei da Ação Civil Pública (art. $8^{\circ}, \S 1^{\circ}$ ), é o inquérito civil, a cargo do Ministério Público, que o preside, na forma do artigo 90, do CDC. Também previsto no art. $51, \S 4^{\circ}$, da codificação consumerista que o Ministério Público poderá exercer controle sobre cláusulas abusivas, a requerimento do consumidor, providência que o legislador foi buscar no sistema francês, onde essas disposições contratuais são controladas por um órgão administrativo, a Commission de Clauses Abusives, criada por uma das Leis Scrivener, o art. 35 da lei n. 78-23, de 10 de janeiro de 1978, regulamentada pelo decreto $\mathrm{n}$. $78-464$, de 24 de março de $1978 .{ }^{24}$

O $\S 3^{\circ}$ do art. 51 do Código de Defesa do Consumidor foi vetado pelo Poder Executivo sob o argumento de que o dispositivo agredia os perfis constitucionais que reservam ao Poder Judiciário o controle geral dos atos

22 Cândido Rangel Dinamarco, Manual, cit., passim.

23 Pierre Godé, Dictionnaire, cit., p. 38-9; Carlos Ferreira de Almeida, Os direitos dos consumidores, Coimbra, Livr. Almedina, 1982, p. 35-9.

24 Sobre o assunto, v. Pierre Godé, Dictionnaire, cit., p. 83-6. 
jurídicos (art. $5^{\circ}, \mathrm{XXXV}$, da CF), bem como de que as atribuições do Ministério Público são fixadas em lei complementar, não podendo a lei ordinária fazê-lo. O veto foi mantido.

É de se registrar, todavia, que o impedimento para a instauração do inquérito civil só prevalece quanto ao controle pelo parquet das cláusulas abusivas, pois continua o mesmo órgão habilitado a instaurá-lo visando a defesa de outros direitos do consumidor, em face da referência expressa que o art. 90 do Código de Defesa do Consumidor faz ao mesmo inquérito e à remissão à lei n. $7.347 / 85$, cujos arts. $1^{\circ}, \mathrm{IV}, 8^{\circ}$ e $9^{\circ}$ disciplinam essa providência a cargo do Ministério Público.

É o inquérito civil uma providência preparatória para a propositura das ações civis coletivas, visando o resguardo de interesses difusos e coletivos dos consumidores, cuja atribuição ao Ministério o foi com muito acerto e coerência, uma vez que é o Parquet, além de órgão independente na fiscalização do cumprimento das leis em geral, também o principal legitimado ativo para promover judicialmente os mecanismos de defesa do consumidor. Constitui tutela preventiva típica.

O Código de Defesa do Consumidor instituiu ainda outras medidas preventivas típicas, tais como a busca e apreensão, a remoção de coisas e pessoas, o desfazimento de obra e o impedimento de atividade nociva, para assegurar o sucesso do processo principal (art. $84, \S 5^{\circ}$ ). A tutela preventiva, nesses casos, é essencialmente assecuratória. Além disso, a codificação autoriza o juiz a conceder liminarmente a tutela postulada pelo consumidor, sempre que, sendo relevante o fundamento da demanda, houver justificado receio de se tornar ineficaz a sentença final (art. 84, $\S 3^{\circ}$ ), caso em que a tutela toma o caráter de antecipatória.

Por fim, em tema de tutela preventiva, possui ainda o ordenamento processual brasileiro um sistema de medidas cautelares nominadas (arts. 813 a 851 do CPC) e inominadas (art. 798 do (PC), que poderão ser utilizadas para a defesa do consumidor, como tutelas atípicas.

\subsubsection{Das condições de exercício da tutela jurisdicional}

Salvo as poucas normas que introduzem modificações parciais nos institutos da legitimação ativa, intervenção de terceiros, litisconsórcio, contraditório, despesas processuais, ônus da prova e coisa julgada, não contém o novo Código de Defesa do Consumidor disciplina processual própria para regular o procedimento dos mecanismos jurisdicionais que criou para a proteção do consumidor, de modo que praticamente toda a matéria pertinente ao setor está subordinada à legislação processual comum, através do Código de Processo Civil, para o qual remete a própria lei especial como encontra-se disposto no artigo 90 do CDC. 
Deste modo, ditos mecanismos estão sujeitos, no que não for expressa a referida lei especial, aos requisitos exigidos para a regularidade do processo e aos pertinentes ao exercício do direito (ou poder) de ação, vale dizer, aos pressupostos processuais e às condições da ação (art. 267, IV e VI, do CPC) e a outros modos e estilos procedimentais a que se subordina a prática do processo comum.

\subsubsection{Da legitimação dos entes coletivos}

Quanto à legitimação ativa, que implementa para o processo civil pátrio, uma das condições da ação, a lei especial possui disciplina própria, adotando-se legitimação extraordinária, mediante a qual ficam autorizados o órgão do Ministério Público, as pessoas jurídicas de natureza política e de existência necessária (União, Estado, Municípios, Distrito Federal), as pessoas jurídicas de natureza administrativa pública direta e indireta, bem como as pessoas jurídicas de direito privado (associações de consumidores) a promover, na qualidade de autores, os mecanismos processuais chamados ações coletivas (art. 82 do CDC). A melhor doutrina tem-na classificação de legitimação concorrente ou disjuntiva. ${ }^{25}$

No processo civil comum, a legitimação ordinária é a curial, na qual legitimado ativo para desencadear o processo é o próprio sujeito que se afirma titular do direito a respeito do qual postula a tutela estatal, de modo a haver coincidência entre o titular do direito afirmado e o titular ou autor da ação judicial.

O Código de Defesa do Consumidor, seguindo a tradição das legislações da espécie no concerto do mundo ocidental, notadamente a dos sistemas francês, alemão, português, espanhol e italiano, optou pela legitimação extraordinária, que caracteriza o fenômeno da substituição processual. Esta significa o exercício do direito (ou poder) de ação, em nome próprio, por quem não é titular do direito afirmado e a respeito do qual é pedida a tutela estatal. E por ser extraordinário tal tipo de legitimação, só existe por expressa determinação legal, que, para a defesa das relações de consumo, está no art. 82 da codificação especial.

\subsubsection{Da intervenção de terceiros}

No que diz com a intervenção de terceiros, está vedada a denunciação da lide, que é obrigatória pela lei processual comum (art. 70, III, do CPC), nas ações de regresso do comerciante co-responsável pelo fato do produto, contra os outros coresponsáveis pela indenização ao consumidor, que são o fabricante, o

25 Entre nós, José Carlos Barbosa Moreira, A legitimação para defesa dos interesses difusos no direito, in Temas, cit., p. 183-92. 
produtor, o construtor e o importador (arts. 12, 13 e 88 do CDC). Dita ação de regresso pode ser ajuizada em processo autônomo, facultando-se ao titular do direito de regresso o procedimento nos próprios autos da ação de responsabilidade civil (art. 88).

A denunciação da lide ao Instituto de Resseguros do Brasil está vedada na ação de responsabilidade civil que o consumidor vier a mover contra o fornecedor de produtos ou serviços, quando este houver contratado o seguro adequado para cobrir eventuais prejuízos decorrentes da atividade explorada (art. 101).

Quanto ao chamamento ao processo (art. 101, II) e ao litisconsórcio (arts. 94 e 103, $\S 2^{\circ}$ ) admitidos pela lei especial, não há singularidades a registrar, uma vez que não distoam dos princípios da lei processual comum (CPC, arts. 46-49 e 77-80) que os define e regula exaustivamente. É mister, porém, se registre a impropriedade dos argumentos jurídicos para justificar o veto ao litisconsórcio facultativo entre os órgãos do Ministério Público da União, Estados e Distrito Federal, admitido no $\S 2^{\circ}$ do art. 82 , porquanto o instituto do litisconsórcio é regulado por lei ordinária, no caso a lei processual civil comum, e não por lei complementar. Além disso, a própria Constituição Federal (art. 129, III) outorga legitimação ao Ministério Público para promover a ação civil pública, que é mecanismo processual adequado à tutela dos interesses difusos e coletivos do consumidor, na qualidade de autor, posição processual que abrange, absorve ou se confunde com a de litisconsorte. Assim, a autorização para o Parquet assumir a posição de litisconsorte em ditas ações já está expressa na Constituição, o que até dispensaria a referência feita no art. 82, $\S 2^{\circ}$, do Código de Defesa do Consumidor. De tal sorte, as razões jurídicas suscitadas pelo Poder Executivo para a sustentação do veto são, no mínimo, questionáveis.

No que pertine à vedação ao Instituto de Resseguros do Brasil de integrar o contraditório (art. 101, II, do $\mathrm{CDC}$ ), registra-se equívoco do legislador, ao proscrever, por lei especial sujeita ao rito ordinário do processo legislativo, o exercício de postulado constitucional universalmente contemplado nos sistemas processuais, nas Cartas Políticas dos Estados modernos e expressamente assegurado, como garantia fundamental, pelo art. $5^{\circ}, \mathrm{LV}$, da atual Constituição brasileira. É, pois, manifesta a inconstitucionalidade do dispositivo legal referido, que próbe ao Instituto de Resseguros do Brasil integrar o contraditório, podendo esta ser alegada perante o Poder Judiciário pelo sistema difuso (art. 97 da CF) ou pelo concentrado (arts. 102, I a, e 129, IV, da CF).

\subsubsection{Das despesas processuais}

Quanto às despesas processuais, a lei especial dispensa o adiantamento delas pelo autor nas ações coletivas e seu pagamento pelo autor vencido, no 
caso de improcedência da ação, salvo hipótese de comprovada má-fé (art. 87 do CDC). No caso de litigância de máfé, respondem solidariamente pelo décuplo das custas e honorários advocatícios a associação autora e os diretores responsáveis pela propositura da ação, independentemente da responsabilidade por perdas e danos, conforme dispõe o artigo 87, parágrafo único da dita lei especial.

\subsubsection{Do ônus da prova e sua inversão}

Classicamente, o ônus da prova ou dever de provar funda-se na passagem do Digesto segundo a qual ei incumbit probatio qui dicit, non qui negat (D 22.3.2).

No incomensurável campo da responsabilidade civil, tema que, por sua grandeza, modernamente exerce invulgar influência no âmbito do direito obrigacional, o onus da prova, ou carga probatória, segundo a preferência dos ordenamentos de origem hispânica, trilha simetricamente os mesmos caminhos percorridos por aquele setor da ordem jurídica.

Com efeito, a teoria clássica sobre a responsabilidade civil sempre se amparou nos postulados da liberdade e da igualdade, que, revigorados enfaticamente com o evento sócio-políticojurídico da Revolução Francesa, tiveram efetiva influência nas relações jurídicas, porquanto o outro postulado, o da fraternidade, foi desde logo esquecido.

A liberdade, na concepção dos inspiradores do sistema, irradiava-se dinamicamente sob o influxo de três princípios cardeais: o da autonomia da vontade, o do efeito relativo dos contratos e o da responsabilidade subjetiva, decorrente da culpa.

Com base no primeiro, a autonomia da vontade, abria-se para o contratante uma tríplice perspectiva: contratar ou deixar de fazê-lo, escolher com quem contratar e estabelecer o conteúdo das obrigações assumidas. Para os consumidores, a experiência vinha demonstrando que os desníveis econômicos e sociais entre ele e o fornecedor não the permitiam exercer em sua plenitude a manifestação autônoma da vontade, devido ao maior aparato de poder de barganha conferido a este em detrimento daqueles.

No que diz com o efeito relativo, expresso no aforismo latino res inter alios acta ou pela forma anglo-saxônica privity of contract, a teoria clássica vinha demonstrando que a vontade própria era fonte fundamental das obrigações, de modo que os efeitos dos contratos deviam restringir-se às partes intervenientes, norma que estava presente na lei civil brasileira de 1916 (art. 928 do Código Civil), dito princípio criava embaraços à relação de consumo que se insere numa cadeia plurissubjetiva formada por fabricante, fornecedor, importador, comerciante, restando o consumidor como o último elo da cadeia e, em razão disso, impotente para reclamar o descumprimento do contrato contra 
outro sujeito que não seja o que com ele contratou. O dispositivo pertinente ao efeito relativo não foi repristinado na vigente codificação civil, que contempla com muita ênfase a função social do contrato, expressa no artigo 421 e, ainda, no artigo 2.035, parágrafo único. Além disso, estabelece regras especiais a respeito dos contratos de adesão, nos artigos 423 e 424 , recomendando interpretação mais favorável ao aderente, quando nesses contratos houver cláusulas ambíguas ou contraditórias e bem assim eivando de nulidade cláusulas que estipulam renúncia antecipada do aderente. Amplia, assim, a nova codificação civil as disposições pertinentes ao assunto, contidas no artigo 51 do CDC.

O terceiro aspecto da teoria liberal é que a aferição da responsabilidade civil do contratante restava submetida ao pressuposto da culpa. Este requisito, em tema de relações de consumo, poderia tornar-se injusto ou até iníquo, pelas dificuldades da prova de culpa do fornecedor, em razão da disparidade de armas com que conta o consumidor para enfrentar a parte mais forte. No entanto, diante de tais dificuldades do consumidor, o CDC adotou a teoria da culpa presumida do fabricante, produtor ou fornecedor, no artigo 12 , dessa codificação especial.

O outro grande postulado da teoria liberal, que se posta ao lado da liberdade, é o da igualdade. Embora este se ampare em indiscutível imperativo humanístico, há que se distinguir entre igualdade formal e igualdade real. Aquela, que se encontra enunciada e proclamada pelo princípio liberal, não encontra equivalência na última, que se abriga na posição econômica desfrutada pelas partes. Assim, das condições econômicas mais frágeis do consumidor resulta a desigualdade entre ele e o fornecedor, economicamente mais forte.

Essas desigualdades, que se vinham verificando a partir da metade do século XIX para cá, restaram por infundir na consciência dos juízes, doutrinadores e, finalmente, dos legisladores a idéia de restabelecer a igualdade real nos contratos, substituindo o contrato liberal pelo contrato social. E, para que isso fosse factível, evolui-se da tradicional teoria da culpa da presunção de culpa com nexo casual, a que se chamou teoria objetiva ou do risco, agora proclamada no artigo 12 do CDC, não obstante a tomada de outras transformações na área contratual, inclusive com o desaguamento desta teoria intermediária na do risco exarcebado, que é observada nas atividades nucleares, nas quais é desconsiderado inclusive o nexo casual. ${ }^{26}$

Outra providência para assegurar

26 Carlos Alberto Bittar, Responsabilidade civil, cit., n. 23-33, p. 29-42;

Responsabilidade civil nas atividades nucleares, São Paulo, Revista dos Tribunais, 1985 , n. 21-30, p. 146-222. 
essa técnica de amenização da teoria clássica, adotou-se, dentre outros engenhos já referidos, o da inversão do ônus da prova. ${ }^{27}$

A primeira manifestação no contexto do direito comparado, a respeito da inversão do ônus da prova, operou-se no campo da jurisprudência. E foram os tribunais americanos, desde 1916, mediante uma consciência de injustiça sugerida pela interpretação restrita do princípio da culpa, que passaram a admitir a amenização deste com base no entendimento de que devia ser alargada a idéia do dever geral de cuidados dos empresários com os produtos de seu fabrico, colocados no mercado (reasonable care), e de informação sobre seu uso (duty of warn).

Tal concepção teve início em 1916, com o caso Mac Pherson v. Buich Motor Co., nos Estados Unidos. Seguiu-se com o caso Donoghue $v$. Stevenson, na Inglaterra, em 1932; com uma decisão do Supremo Tribunal italiano, de 1964; e com a sentença do Supremo Tribunal alemão (Bundesgerichtshof) no famoso caso sobre a "peste dos frangos" (Hühnerpest Urteil), considerado o leading case no direito tedesco sobre o assunto. ${ }^{28}$

$\mathrm{Na}$ Espanha, onde os tribunais também já vinham construindo a aplicação do princípio em favor do litigante mais franco, foi a inversão do ônus da prova expressamente contemplada no art. $1^{\circ}$, letra $c, \S 8^{\circ}$, da "ley General para la Defensa de los Consumidores y Usuarios" (ley 19 julio 1984, 26/84), que dispõe: Las cláusulas, condiciones o estipulaciones que, com carácter general, se apliquen a la oferta, promoción o venta de productos o servicios, incluidos los que faciliten las Administraciones públicas y las Entidades y Empresas de ellas dependientes, deberán cimplir los seguientes requisitos: ... c) Buena fe y iusto equilibrio de las contraprestaciones lo que, entre otras cosas, excluye: $\ldots 8^{\circ}$ La inversión de la carga de la prueba em prejuicio del consumidor o usuario.

A lei portuguesa (lei n. 29/81, de 228-1961), denominada Lei de Defesa do Consumidor, omitiu-se não só acerca da responsabilidade objetiva do fornecedor como também quanto ao ônus da prova, o que nos leva a concluir que a matéria ainda se situa em campos da teoria clássica, isto é, a responsabilidade do produtor é a subjetiva, ${ }^{29}$ naquele sistema.

No Brasil, já de algum tempo para cá, especialmente após a década de 30

27 Carlos Alberto Bittar, Responsabilidade civil, cit., n. 24, p. 31-2.

28 Carlos Ferreira de Almeida, Os direitos, cit., n. 34-36, p. 134-9; Luiz Gastão Paes de Barros Leães, A responsabilidade, cit., p. 36, 42 e 67; Alpa e Bessone, $L a$ responsabilità del produtore, Milano, Giuffrè, 1987, p.113 es.

29 Carlos Ferreira de Almeida, Os direitos, cit., p. 134, nota 154. 
do século recém findo, quando começaram a esboçar-se as primeiras escaramuças dos direitos sociais em nossa Pátria, passou a doutrina a propor timidamente a adoção de um temperamento da responsabilidade subjetiva, adotada pelo Código Civil, visando reequilibrar certas relações jurídicas contratuais ou extracontratuais onde um dos sujeitos se apresentasse como personagem mais fraco. A esse propósito doutrinal seguiu-se um acolhimento da jurisprudência e posteriormente da legislação para casos esporádicos. Tais eram as hipóteses de acidentes do trabalho, no campo da infortunística; dos acidentes ferroviários; dos acidentes resultantes de certas atividades perigosas, especialmente os decorrentes de atividades nucleares, onde há a máxima exarcerbação da responsabilidade, com desconsideração inclusive do nexo causal.

Para obviar a reparação dos danos decorrentes dessas atividades, a jurisprudência passou a admitir a presunção de culpa do agente da atividade ou do serviço, em razão do risco por este assumido ao colocá-lo à disposição do público. E assim o primeiro passo para reequilibrar as situações descompassadas pela disparidade de forças e obter a plena responsabilidade e reparação do prejuízo era a inversão do ônus da prova.

Tal doutrina sensibilizou, em termos amplos, o legislador constituinte de 1988, ao alargar sobremodo, quiça exage- radamente, os direitos sociais, de modo a desequilibrar os contrapesos dos pratos da balança para o outro pólo, em detrimento da justiça contratual o que pressagiamos, oxalá não aconteça. Nessa linha, introduziu-se amparo amplo às atividades de consumo em geral, com significativa tutela à pessoa do consumidor.

E, com a edição do Código de Defesa do Consumidor, através da lei n. 8.078 , de 11 de setembro de 1990 em vigor a partir de 11 de março de 1991, instituiu o legislador a inversão do ônus da prova, qualificando-a como direito básico do consumidor, no art. $6^{\circ}$, VIII, da codificação.

Vê-se, pela redação do dispositivo legal, que a inversão do onus probandi não constitui princípio absoluto que deva ser aplicado na generalidade dos casos e sem exceção. É, sem dúvida, um princípio que se encontra relativizado por condicionamentos a serem aferidos no caso concreto, mediante prudente critério judicial, quando a alegação do consumidor for verossimil, ou quando for ele considerado hipossuficiente, diga-se, litigante mais fraco, segundo as regras ordinárias da experiência.

Em várias outras passagens da codificação o princípio encontra-se direta ou indiretamente admitido, tal como acontece nos textos do artigo 12 , $\S 3^{\circ}$; no do artigo 14 , caput e $\S 3^{\circ}$; nos artigos 23 e 38; e também no artigo 51, inciso VI. 